\title{
Elevated Vertical-Flow Constructed Wetlands for Light Greywater Treatment
}

\author{
Carlo Morandi * (D), Gerhard Schreiner, Patrizia Moosmann and Heidrun Steinmetz
}

check for updates

Citation: Morandi, C.; Schreiner, G.; Moosmann, P.; Steinmetz, H. Elevated Vertical-Flow Constructed Wetlands for Light Greywater Treatment. Water 2021, 13, 2510. https://doi.org/ $10.3390 / w 13182510$

Academic Editors: Amit Gross and Zeev Ronen

Received: 1 August 2021

Accepted: 9 September 2021

Published: 13 September 2021

Publisher's Note: MDPI stays neutra with regard to jurisdictional claims in published maps and institutional affiliations.

Copyright: (C) 2021 by the authors. Licensee MDPI, Basel, Switzerland. This article is an open access article distributed under the terms and conditions of the Creative Commons Attribution (CC BY) license (https:/ / creativecommons.org/licenses/by/ $4.0 /)$.
Department for Resource-Efficient Wastewater Technology, Faculty of Civil Engineering, Technische Universität Kaiserslautern, Paul-Ehrlich-Straße 14, 67663 Kaiserslautern, Germany; schreinergerhard@gmx.net (G.S.); paddy.mo97@gmx.de (P.M.); heidrun.steinmetz@bauing.uni-kl.de (H.S.)

* Correspondence: carlo.morandi@bauing.uni-kl.de; Tel.: +49-631-205-2948

\begin{abstract}
Integrated planning of urban blue-green infrastructures is crucial to strengthen urban environmental quality and mitigate negative climate change-associated effects. It implies, however, increased water demand for irrigation, wherefore greywater (wastewater excluding wastewater from toilets and urinals) can be used, yet it requires handling for safe reuse. One treatment option is the use of constructed wetlands (CW), which have thus far not been broadly applied in inner-city districts due to large area requirements. This work investigates a novel bipartite container-based vertical-flow constructed wetland (VFCW) for the treatment of light greywater (from showers and hand wash basins) and its use as irrigation water for urban facade greenery. The VFCW consists of two compartments with $2.5 \mathrm{~m}^{2}$ filter area each, filled with $75 \mathrm{~cm}$ zeolite-containing lava sand $(0-4 \mathrm{~mm})$ and $75 \mathrm{~cm}$ Rhine sand $(0-2 \mathrm{~mm})$, respectively. In short, screening has proven to be well suitable for coarse solids removal, so there is no further need to settle light greywater, which reduces overall treatment area and benefits urban application. Treated greywater complied with irrigation standards at all times, yet mixing with rainwater can help reduce salt contents, if applicable. The modular/elevated lava sand VFCW exhibited extensive nitrification, even at extremely low water temperatures, as well as mean effluent concentrations of $6.3 \mathrm{mg} / \mathrm{L} \mathrm{COD}$ and $<0.05 \mathrm{mg} / \mathrm{L} \mathrm{P}_{\text {tot }}$, which makes it a very promising treatment option for greywater. All in all, the modular/elevated design promotes urban application of VFCW as a multifunctional blue-green system that can help increase urban resilience.
\end{abstract}

Keywords: blue-green infrastructures; container-based; lava sand; low temperature; nature-based solutions; nitrification; phosphorus

\section{Introduction}

Man-made climate change gives rise to higher global mean temperatures and an increased incidence of extreme weather events, e.g., heat stress, heavy rainfalls, prolonged droughts, which dramatically worsen existing local environmental stresses as a result of urbanization, such as the urban heat island effect, flooding, water shortages etc. [1,2]. Bluegreen infrastructures (BGI), strategically planned networks of natural and semi-natural areas consisting of vegetative and water-related elements, offer a solution to mitigate the negative effects of climate change in cities [3]. BGI deliver a variety of ecosystem services and can provide environmental, economic and social benefits, thus leading to a higher quality of life, by e.g., increasing biodiversity and enhancing microclimate through shading, evaporative cooling, thermal insulation, etc. [4,5]. However, the implementation of BGI comes along with a significant increase in water demand, as these infrastructures require water for maintenance (irrigation, among others), which may further restrain conventional water resources, such as groundwater, surface water, bank filtrate, etc.

In order to alleviate drinking water supply systems and meet raising water demands, while simultaneously strengthening BGI in urban areas, it is imperative that unconventional 
urban water resources are exploited and supplied in adequate quantity and quality, e.g., greywater (wastewater excluding toilet and urinal wastewater [6]), effluent of wastewater treatment plants (WWTP), and/or other effluents. This practice has thus far been adopted particularly in countries with high water stress, e.g., Israel (see e.g., $[7,8]$ ) and Australia (see e.g., $[9,10]$ ), among others, etc. German quality standards for irrigation water, DIN 19650 (1999) [11] and DIN 19684-10 (2009) [12] are relatively strict, when compared to international standards (see [13-15]) and may require updating, as these documents were published over a decade ago. Furthermore, rainwater is often used as an alternative water source, but is typically insufficient to meet the raising water demand in densely built-up areas due to high storage capacities required and the lack of urban space. Moreover, prolonged periods of drought, propelled by climate change, further restrain rainwater harvesting. In contrast to rainwater, greywater is produced continuously at the source, thus requiring minor storage capacities, which makes it a good complementary water resource. However, handling is necessary for safe reuse (see [11-13]).

The most widely applied technologies for greywater treatment are filtration, moving bed biofilm reactors (MBBR), membrane bioreactors (MBR), constructed wetlands (CW), among others [16]. CW are a consolidated technology for municipal wastewater treatment. For greywater treatment, vertical-flow constructed wetlands (VFCW) can meet strict chem$\mathrm{ical} / \mathrm{physical}$ standards for water reuse and, in terms of BOD (85\% removal on average, $10 \mathrm{mg} / \mathrm{L}$ mean $\mathrm{BOD}_{5}$ effluent concentration; see [17]) and TSS, perform as well as or better than CW for municipal wastewater [17] and usually perform best compared to other CW designs, such as free water surface and horizontal subsurface flow constructed wetlands (HFCW) [18]. Stefanakis et al. (2014) [19] reported overall VFCW performance of $85 \%$ for BOD $_{5}$ (min-max: $48-99 \%$ ) and $75.2 \%$ for COD (min-max: 44-95\%). In addition, CW are of simple operation, low-cost and, if planted, aesthetically pleasant, and they promote biodiversity and offer cooling effects [20-22], which are clear advantages over purely technical treatment systems. Nevertheless, CW typically require large filter areas for treatment, which have so far limited their application in urban centers [20]. In contrast, MBR and MBBR represent compact solutions for densely urbanized areas [23], yet they are more energy and resource-intensive and exhibit higher operating costs.

German guidelines DWA-A 262 (2017) [24] discourage the use of HFCW as a main treatment step for municipal wastewater and wastewater streams, e.g., greywater, since unaerated HFCW do not offer sufficient ammonium nitrogen elimination due to anaerobic milieu conditions resulting from the water-saturated operation; assuming a nitrogen-rich influent water, high ammonium concentrations $\left(\mathrm{NH}_{4}{ }^{+}-\mathrm{N}\right)$ would be present in HFCW effluent [25], thus posing a risk to the environment. Correspondingly, there is not sufficient experience with unaerated HFCW in Germany [24]. Following the German guidelines, the present study has therefore focused on VFCW for greywater treatment. However, little focus has thus far been laid on sizing of $\mathrm{CW}$ for the treatment of greywater, let alone light greywater. Even though there has been progress worldwide in developing guidelines which include CW sizing for greywater treatment, German guidelines (see [24]) state that the required CW filter area for greywater treatment can be set to $50 \%$ of the area required for municipal wastewater, which is a vague statement. Additionally, in many countries, guidelines for $\mathrm{CW}$ designs are still limited to domestic sewage, while first guidelines to design CW to treat greywater are being elaborated.

In order to extend the field of application of CW to inner-city areas, severely affected by climate change, this study investigates an elevated container-based bipartite VFCW to treat light greywater from showers and washing basins at a construction workers' housing site in Stuttgart North in Germany. The collected light greywater is treated in two different filter chambers filled with (1) zeolite-containing lava sand $(0-4 \mathrm{~mm})$ and (2) conventional Rhine sand ( $0-2 \mathrm{~mm})$, respectively. The filter innovation consists mainly of the elevated and modular design, the possibility of a simplified treatment by solely treating the light greywater fraction and the use of a novel zeolite-containing lava sand as filter media. Treated water is used as irrigation water for urban facade greenery. In 
addition, the necessity of a pretreatment (e.g., multi-chamber septic tank) is discussed. Moreover, this work investigates the cleaning performances of both filter compartments at low and very low water temperatures. Subsequently, irrigation suitability is assessed by comparing effluent values with German and international irrigation standards. Based on lessons learned and treatment efficiency results, the technical feasibility of the elevated design is evaluated. Finally, recommendations are given for the application of elevated VFCW to treat light greywater in urban areas.

\section{Materials and Methods}

This work addressed the low-temperature operation of an elevated bipartite containerbased VFCW with a total filter area of $5 \mathrm{~m}^{2}$ to treat light greywater, as shown in Figure 1. Reclaimed water is applied for urban facade greenery irrigation, as depicted in Figure 1. The elevated VFCW is planted with commercially available reeds (Phragmites australis) and consists of two compartments with $2.5 \mathrm{~m}^{2}$ filter area each, filled with $75 \mathrm{~cm}$ zeolitecontaining lava sand $(0-4 \mathrm{~mm})$ and $75 \mathrm{~cm}$ Rhine sand $(0-2 \mathrm{~mm})$, respectively. Drainage layers of $25 \mathrm{~cm}$ gravel ( $2-8 \mathrm{~mm}$ ) support the respective filter media. Lava sand was acquired from a quarry in Lissingen in Germany and exhibits an increased clay content (of $>2 \%$ ) as well as a natural zeolite content of approx. $10 \%$. The Rhine sand used is commercially available fluviatile sand. The VFCW is a core component of the Impulse Project Stuttgart, an urban compact demonstration and research implementation of resilient climate change adaption measures, situated within the future Rosenstein district in Stuttgart North in Germany (further information can be found in Eisenberg et al. (2021) [26]). A schematic flow diagram of the Impulse Project Stuttgart is depicted in Scheme 1. All measuring devices and sensors are controlled via an IRRInet ACE control unit (Mottech Water Solutions Ltd., Rosh Haayin, Israel).

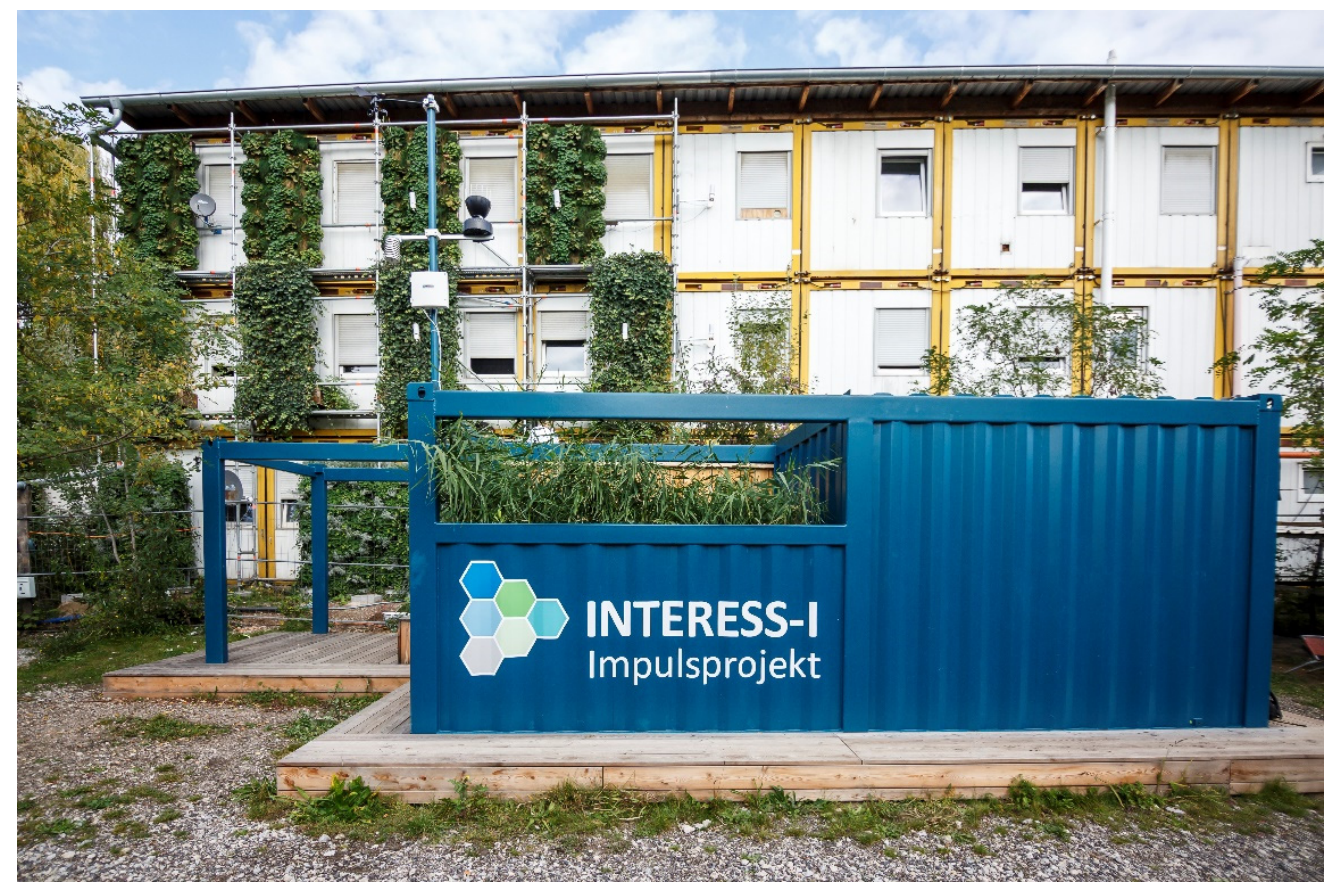

Figure 1. Front view perspective of the modular container-based vertical-flow constructed wetland (VFCW) to treat light greywater from showers and handwash basins for use as irrigation water for the building facade (Photo: J. Rettig). 


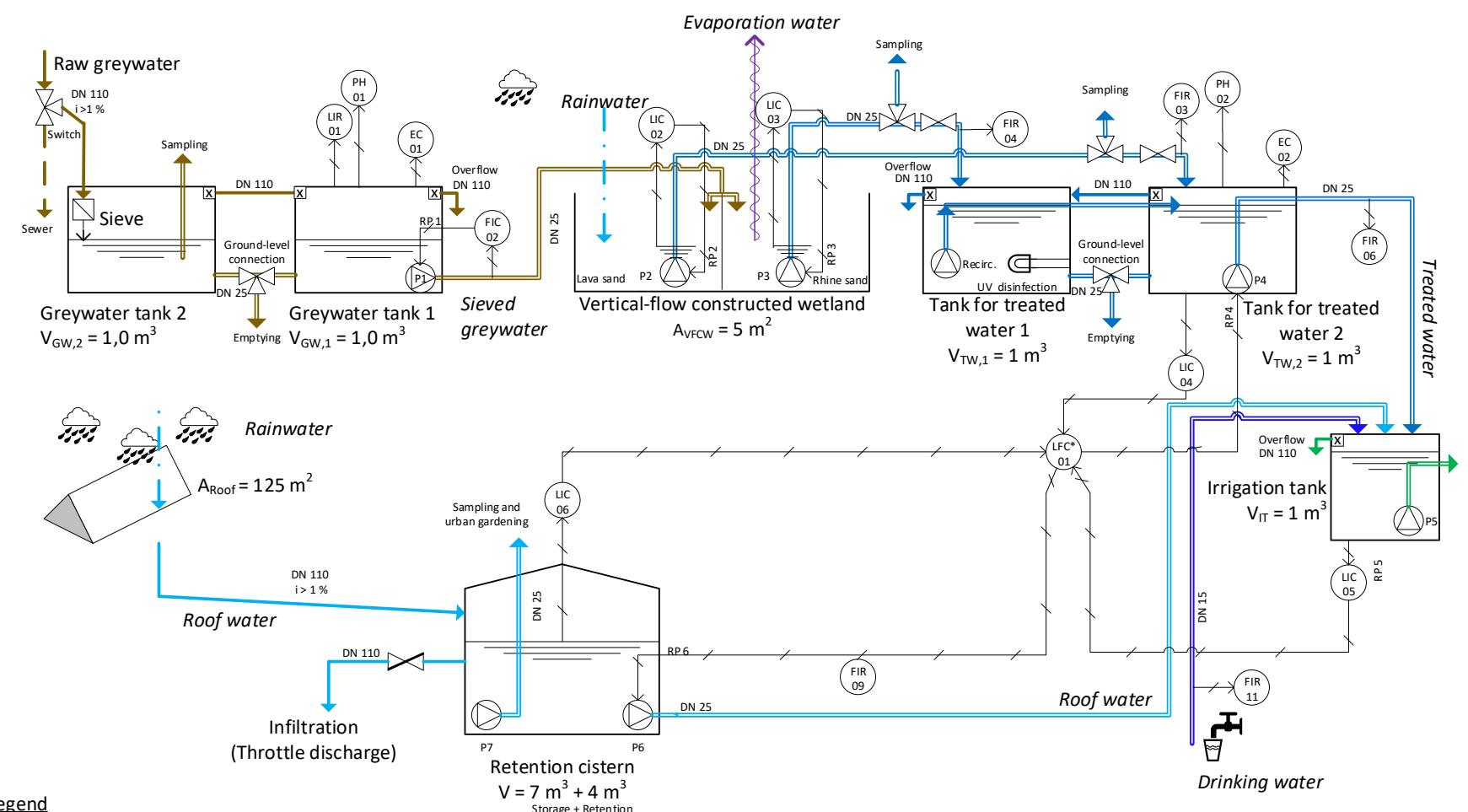

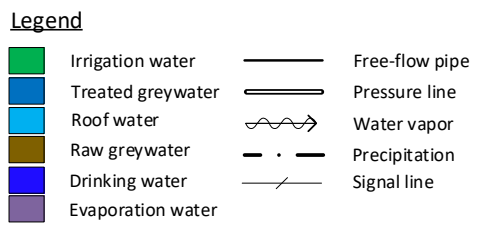
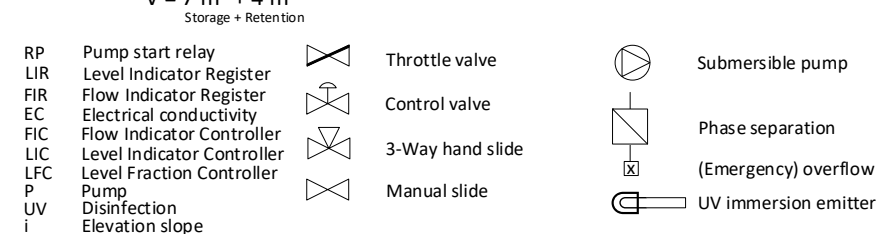

Scheme 1. Flow diagram of the Impulse Project Stuttgart with water path, volume, and area specifications as well as control logics (irrigation section not shown).

Greywater is collected from shared bathrooms (hand wash basins and showers) at a container-based workers' housing site (see Figure 1) to which 10 apartment units are connected. Already existing separated greywater and blackwater pipes considerably reduced construction effort in retrieving graywater at the workers' housing site. Through a free-flow pipe, light greywater is routed into a storage with a total volume capacity of $2 \mathrm{~m}^{3}$, consisting of two Intermediate Bulk Containers (IBC) (see Scheme 1). At the inlet, a screen (mesh width: $1.3 \mathrm{~mm}$, Green Life $\mathrm{GmbH}$, Schwerin, Germany) retains coarse solids and is cleaned regularly (once to twice a month). Although no further pretreatment is applied, the storage tanks contribute to the settling of solids in light greywater and are emptied and cleaned once every four months. Six times per day, screened light greywater is intermittently fed to the VFCW by a submersible feeding pump (Ama-Drainer N 301, KSB SE \& Co. KGaA, Frankenthal, Germany). Feeding time does not exceed $1 \mathrm{~min}$, so screened greywater is distributed rapidly and evenly over the entire filter area. Baffle plates, on which the distribution pipes are placed, avoid the formation of cavities into the upper filter layer that may otherwise lead to channeling. After percolating through the respective filter chamber, treated water is pumped by two flat suction pumps (Homa C $80 \mathrm{~W}$, HOMA Pumpenfabrik, Neunkirchen-Seelscheid, Germany) into a $2 \mathrm{~m}^{3}$ large storage (see Scheme 1), respectively, where both effluents are mixed and further disinfected by an UV immersion emitter (Aquaforte $40 \mathrm{~W}$, SIBO Fluidra Netherlands B.V., Veghel, Netherlands), which is coupled to a circulation pump (ZM 280, Zehnder Group Deutschland GmbH, Lahr, Germany).

In addition to greywater, rainwater from roofs $\left(125 \mathrm{~m}^{2}\right.$ area) is collected and stored in a $11 \mathrm{~m}^{3}$ large retention cistern (further information can be found in [26]). Excess rainwater is infiltrated in the soil to promote groundwater recharge. Level-controlled filling of 
the irrigation tank is performed (see Scheme 1) in order to set a definite ratio of treated graywater to rainwater for use as irrigation water. Both $\mathrm{pH}$ and electrical conductivity (EC) are monitored continuously in raw and treated greywater by $\mathrm{pH}$ (202705, JUMO GmbH \& Co. KG, Fulda, Germany) and EC sensors (BlackLine CR-EC, JUMO GmbH \& Co. KG, Fulda, Germany), attached to immersion fittings. However, it is not possible to differentiate between effluents, as both tanks for treated water are hydraulically connected, as can be inferred from Scheme 1, so this data has not been included in the present work. Alternatively, on sampling days, $\mathrm{pH}$ and $\mathrm{EC}$ of raw greywater and both effluents are also determined by WTW portable meters (Xylem Analytics Germany Sales GmbH \& Co. KG, Weilheim, Germany). Additionally, levels and volume flows are continuously measured by ultrasonic level meters (AU006, Autosen GmbH, Essen, Germany) and, within the $\mathrm{CW}$ effluent shafts, by pressure level sensors (AquaBar II, Nivus GmbH, Eppingen, Germany) as well as by water meters (HidroJet $\frac{1}{2} "$, Hidroconta S. A., Murcia, Spain) and, at the VFCW inlet, by a magnetic-inductive flow meter (SM9000, ifm electronic GmbH, Essen, Germany) respectively, as can be inferred from Scheme 1. By change in filling level (raw greywater storage), daily greywater volume flows could be determined, provided that overflow did not occur.

According to the outside air temperature and the feeding volume flow set, VFCW operation was categorized into different operating phases, shown in Table 1; respective hydraulic and COD (chemical oxygen demand) surface loading rates are given for each phase and filter chamber. During Phase 5b, the VFCW was taken out of operation for one week as precaution measure to avoid frost damages on pumps and sensors.

Table 1. Operating phases for the vertical-flow constructed wetland, from July 2020 to March 2021 in Stuttgart North, Germany.

\begin{tabular}{|c|c|c|c|c|c|}
\hline $\begin{array}{l}\text { Operating } \\
\text { Phase }\end{array}$ & $\begin{array}{c}\text { Period } \\
\text { (dd.mm.yy) }\end{array}$ & Filter Chamber & $\begin{array}{c}\text { Hydraulic Surface } \\
\text { Loading Rate in } \\
\mathrm{L} /\left(\mathrm{m}^{2} \cdot \mathrm{d}\right)\end{array}$ & $\begin{array}{c}\text { COD Surface } \\
\text { Loading Rate in } \\
\mathrm{g} /\left(\mathrm{m}^{2} \cdot \mathrm{d}\right)\end{array}$ & $\begin{array}{c}\text { Outdoor Air } \\
\text { Temperature, Daily } \\
\text { Mean (Min/Max) in }{ }^{\circ} \mathrm{C}\end{array}$ \\
\hline \multirow{2}{*}{$\begin{array}{c}1 \\
\text { (start-up) }\end{array}$} & \multirow{2}{*}{$\begin{array}{c}11.07 .2020- \\
08.09 .2020\end{array}$} & Lava sand & 80 (set) & - & 21.2 \\
\hline & & Rhine sand & 80 (set) & - & $(11.3 / 31.3)$ \\
\hline \multirow{2}{*}{2} & \multirow{2}{*}{$\begin{array}{c}09.09 .2020- \\
18.10 .2020\end{array}$} & Lava sand & 73 & 18 & 13.8 \\
\hline & & Rhine sand & 82 & 20 & $(8.4 / 22.6)$ \\
\hline \multirow{2}{*}{3} & \multirow{2}{*}{$\begin{array}{l}19.10 .2020- \\
29.11 .2020\end{array}$} & Lava sand & 63 & 19 & 7.9 \\
\hline & & Rhine sand & 80 & 24 & $(3.2 / 15.1)$ \\
\hline \multirow{2}{*}{$4 a$} & \multirow{2}{*}{$\begin{array}{c}30.11 .2020- \\
21.11 .2020\end{array}$} & Lava sand & 66 & 37 & 2.8 \\
\hline & & Rhine sand & 83 & 46 & $(-0.2 / 7.0)$ \\
\hline \multirow{2}{*}{$4 b$} & \multirow{2}{*}{$\begin{array}{c}22.12 .2020- \\
11.01 .2021\end{array}$} & Lava sand & 18 & 8 & 1.6 \\
\hline & & Rhine sand & 22 & 9 & $(-1.3 / 4.9)$ \\
\hline \multirow{2}{*}{$4 c$} & \multirow{2}{*}{$\begin{array}{c}12.01 .2021- \\
27.01 .2021\end{array}$} & Lava sand & 65 & 15 & 1.4 \\
\hline & & Rhine sand & 83 & 19 & $(-1.9 / 4.9)$ \\
\hline \multirow{2}{*}{$5 a$} & \multirow{2}{*}{$\begin{array}{c}28.01 .2021- \\
10.02 .2021\end{array}$} & Lava sand & 43 & 10 & 4.2 \\
\hline & & Rhine sand & 62 & 14 & $(1.1 / 7.6)$ \\
\hline $5 b$ & $\begin{array}{l}11.02 .2021- \\
17.02 .2021\end{array}$ & $\begin{array}{l}\text { Lava sand } \\
\text { Rhine sand }\end{array}$ & \multicolumn{2}{|c|}{ out of operation } & $\begin{array}{c}-2.0 \\
(-8.8 / 75)\end{array}$ \\
\hline \multirow[b]{2}{*}{$5 c$} & $18.02 .2021-$ & Lava sand & 46 & 10 & 6.0 \\
\hline & 15.03 .2021 & Rhine sand & 56 & 12 & $(-0.4 / 16.6)$ \\
\hline
\end{tabular}

Raw greywater and treated greywater are sampled on a weekly basis (except for holidays); corresponding sampling points are shown in Scheme 1. Sampling of raw greywater is performed directly from the storage tank by means of a sampling scoop attached to a rod, as a multiday composite sample, while treated greywater by each filter compartment is drawn through a respective sampling valve connected to the effluent shaft (see Scheme 1) as a $24 \mathrm{~h}$ composite sample, by temporarily impounding the drainage layers. 
Greywater analysis is carried out in a container lab on-site using Hach Lange LCK cuvette tests and a photometer DR 1900 (Hach Lange GmbH, Düsseldorf, Germany), except for the cations $\mathrm{K}^{+}, \mathrm{Mg}^{2+}, \mathrm{Ca}^{2+}$ and $\mathrm{Na}^{+}$, which are conserved, as explained below, and analyzed by ion chromatography (930 Compact IC Flex, Deutsche METROHM GmbH \& Co. KG, Filderstadt, Germany) in the lab facilities of the Technische Universität Kaiserslautern. $\mathrm{COD}, \mathrm{N}_{\text {tot }}, \mathrm{P}_{\text {tot }}, \mathrm{NH}_{4}{ }^{+}-\mathrm{N}, \mathrm{NO}_{3}{ }^{-}-\mathrm{N}, \mathrm{PO}_{4}{ }^{3-}-\mathrm{P}$ and the investigated cations are measured mostly by double determination, exceptions represent $\mathrm{NO}_{3}{ }^{-}-\mathrm{N}$ in screened greywater and $\mathrm{N}_{\text {tot }}$ in both effluents, which were analyzed by simple determination. $\mathrm{NO}_{2}{ }^{-} \mathrm{N}_{1} \mathrm{Cl}^{-}, \mathrm{SO}_{4}{ }^{2-}$ as well as cationic, anionic, and non-ionic surfactants are measured by simple determination, except for chloride in screened greywater, which is analyzed by double determination. All parameters, except for $\mathrm{Cl}^{-}, \mathrm{SO}_{4}{ }^{2-}$ and surfactants, are determined on a weekly basis, if the opposite is not explicitly stated. In an attempt to reduce the use of chemicals and save labor time, the analysis frequency for surfactants, chloride, and sulfate was set lower than for the remaining parameters, as surfactant determination is time-consuming and chlorides and sulfates are not removed or substantially transformed in the filter. The unfiltered samples for the sum parameters $\mathrm{COD}, \mathrm{N}_{\text {tot }}$ und $\mathrm{P}_{\text {tot }}$ are chemical-thermally digested in a thermostat LT200 (Hach Lange GmbH, Düsseldorf, Germany). Additionally, surfactants are analyzed from the unfiltered sample. Samples for dissolved parameters are filtered with a $0.45 \mu \mathrm{m}$ Minisart RC syringe pre-filter (Sartorius AG, Göttingen, Germany). After filtration, the samples for cation analysis are acidified with concentrated nitric acid to a $\mathrm{pH}$ of 2.5 to 3.5 , deep-frozen at $-18{ }^{\circ} \mathrm{C}$ and analyzed at a later date. The sodium adsorption ratio (SAR) is calculated according to DIN 19684-10 [12]. The biological oxygen demand $\left(\mathrm{BOD}_{5}\right)$ is not investigated, yet expected $\mathrm{BOD}_{5}$ concentration ranges can be estimated based on the determined COD concentrations and typical $\mathrm{COD} / \mathrm{BOD}_{5}$ ratios from the scientific literature.

In this work, while dealing with values below the limit of determination (LOD), a measured value $<$ LOD was replaced by a numerical value $(0.5 \times \mathrm{LOD})$ for data series with a sufficient share $(50 \%)$ on measured values $>$ LOD only, in accordance to [27].

\section{Results and Discussion}

\subsection{Light Greywater Characterization}

Table 2 shows the composition and volume flow of screened light greywater from the temporary workers' accommodation (VFCW influent). An estimated light greywater volume flow of $48 \mathrm{~L}$ per person and day highlights the considerable water potential in such facilities, yet it must be noted that only little greywater was produced on weekends and during company vacations (see Table 2). The varying volume flows can be e.g., counterbalanced by sufficiently large storage tanks (e.g., three days volumes). The median COD concentration for screened light greywater amounted to $258 \mathrm{mg} / \mathrm{L}$, as can be inferred from Table 2, and is similar to literature values for household light greywater $(283 \mathrm{mg} / \mathrm{L}$ COD [28]); the higher mean value of $328 \mathrm{mg} / \mathrm{L} \mathrm{COD} \mathrm{is} \mathrm{attributable} \mathrm{to} \mathrm{two} \mathrm{outliers} \mathrm{of}$ $1039 \mathrm{mg} / \mathrm{L}$ and $779 \mathrm{mg} / \mathrm{L}$, which fell within the range of highly polluted graywater (258-1021 mg/L [28]). Using a calculated COD/BOD 5 ratio in light greywater of 2.05 (see [28]), a $\mathrm{BOD}_{5}$ concentration of $126 \mathrm{mg} / \mathrm{L}$ can be estimated, which is found to lie within the typical range for light greywater $\left(61-188 \mathrm{mg} / \mathrm{L}\right.$, see [28]). Despite sieving, a $\mathrm{N}_{\text {tot }}$ mean concentration of $28.3 \mathrm{mg} / \mathrm{L}$ (see Table 2) was observed, which significantly exceeded expected values for light greywater at the household level (10 mg/L $\mathrm{N}_{\text {tot }}$, see [28]). The high nitrogen content may be an indicative of partial urine contamination in the construction workers' shower water, yet further investigation is needed to support this proposition. On the other hand, phosphorus concentrations $(1.9 \pm 0.5 \mathrm{mg} / \mathrm{L}$, see Table 2) were lower than the expected literature values $\left(2.8 \mathrm{mg} / \mathrm{L}_{\text {tot }}[8], 3.3 \mathrm{mg} / \mathrm{L} \mathrm{P}_{\text {tot }}\right.$ [28]) for bathroom greywater. This may be related to the increased use of low-phosphate detergents and cleaning agents in the workers' housing, exemplified by the alkaline high concentrate Force F (LayerChemie $\mathrm{GmbH}$, Leingarten, Germany), which directly affects greywater composition. The restricted use of phosphates and phosphate compounds in such products is enshrined in 
German law by the Detergents and Cleaning Agents Act [29]. The $\mathrm{pH}$ of $8.4 \pm 0.3$ (see Table 2) lied at the upper end of the expected range for light greywater (5-8.6 [28]), which among others can be attributed by the use of alkaline cleaning agents (Force $\mathrm{F}$ has a $\mathrm{pH}$ value of 13.5). The electrical conductivity of tap water at the Impulse Project (Stuttgart North) was determined to $522 \pm 13 \mu \mathrm{S} / \mathrm{cm}(n=5)$, which elucidates greywater salinization ( $\mathrm{EC}=737 \mu \mathrm{S} / \mathrm{cm}$ on average; see Table 2) through the use of cleaning and personal care products. All in all, the results indicate that greywater characterization is critical for VFCW sizing and project success, as quality can differ significantly from expected literature values.

Table 2. Volume flow and composition of screened light greywater (showers and washbasins) from container-based workers' accommodations in Stuttgart North.

\begin{tabular}{cccccc}
\hline Parameter & Unity & Mean Value \pm Std. Dev. & Median & Min-Max & $n$ \\
\hline Volume flow & $\mathrm{L} / \mathrm{p} \cdot \mathrm{d})$ & $48 \pm 22$ & 42 & $0.4-82$ & 41 \\
\hline $\mathrm{COD}$ & $\mathrm{mg} / \mathrm{L}$ & $328 \pm 211$ & 258 & $197-1039$ & 20 \\
\hline $\mathrm{N}_{\text {tot }}$ & $\mathrm{mg} / \mathrm{L}$ & $28.3 \pm 7.1$ & 27.9 & $19.0-46.8$ & 20 \\
\hline $\mathrm{P}_{\text {tot }}$ & $\mathrm{mg} / \mathrm{L}$ & $1.9 \pm 0.5$ & 1.8 & $1.3-3.2$ & 20 \\
\hline $\mathrm{pH}$ & - & $8.4 \pm 0.3$ & 8.5 & $7.6-8.8$ & 18 \\
\hline $\mathrm{EC}$ & $\mu \mathrm{S} / \mathrm{cm}$ & $737 \pm 51$ & 722 & $678-837$ & 8 \\
\hline
\end{tabular}

\subsection{Plant Development}

The growth and decay of the VFCW reeds during different operating phases can be followed in Figure 2. Already during the first year of operation (see October 2020), microphytes grew extremely well, thus transforming the "technical VCFW" into a genuine blue-green element, which can be easily integrated in the urban landscape design, thus reducing disputes over land developments in inner-city areas.
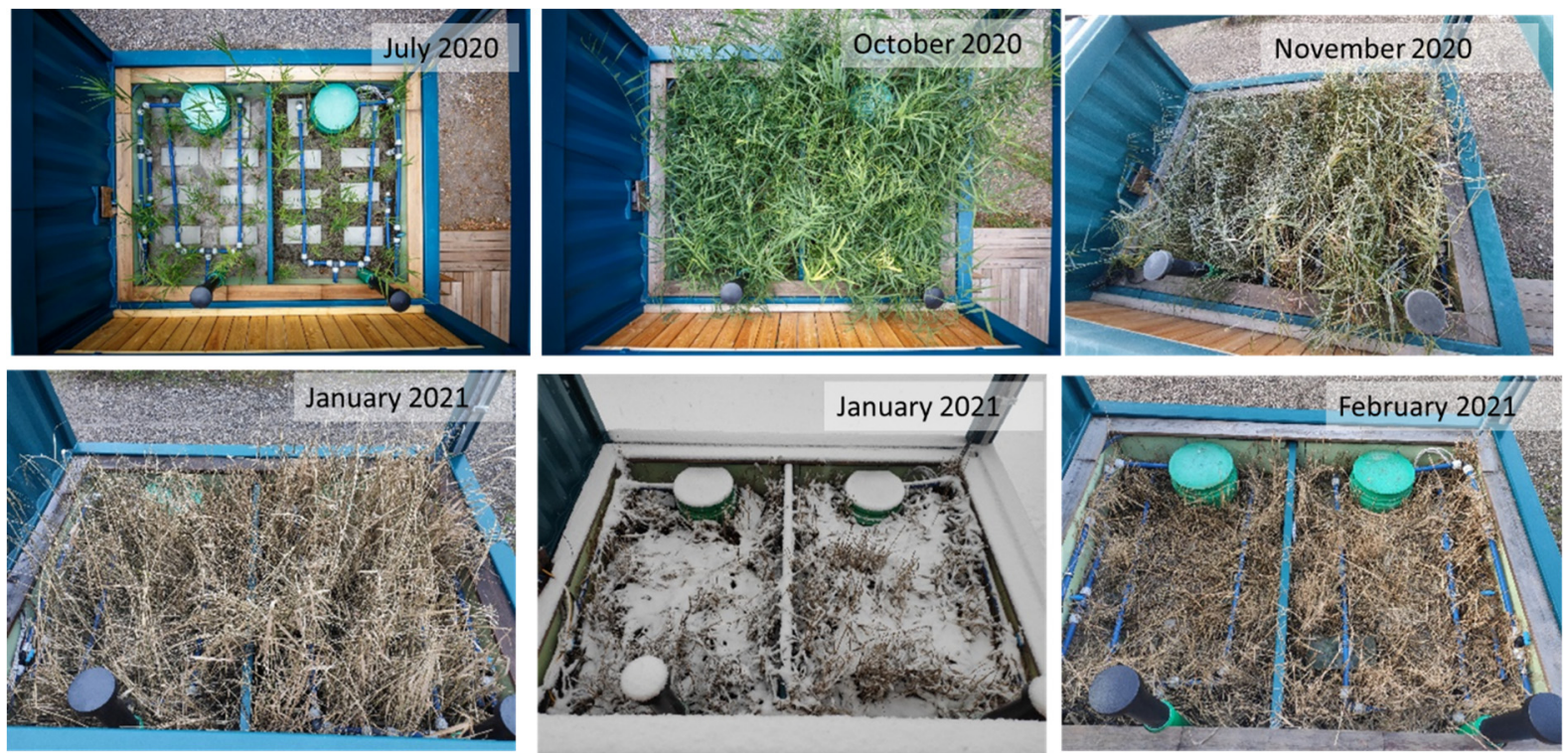

Figure 2. VFCW in different operating phases (Photos: J. Rettig; P. Moosmann).

\subsection{Pretreatment Requirement for Light Greywater}

During VFCW operation, no operational malfunction or failure due to filter clogging has thus far been reported while treating screened light greywater from shared bathrooms. This leads to the conclusion that screening and non-targeted sedimentation in the storage tanks are suitable for removing solid particles from light greywater, so no complex pre- 
treatment (e.g., multi chamber septic tank or settling pond, as recommended in German technical regulations [24]) is required. This finding is explicitly valid for light greywater without kitchen and/or washing machine wastewater only and can significantly reduce area requirements for urban application of VFCW. On a larger scale, the operating effort could be significantly reduced by e.g., using self-cleaning screens or rakes and funnelshaped tank bases with an outlet tap at the bottom to release the solid layer into the sewer on demand.

\subsection{Reduction of Organic Matter}

Table 3 gives a general overview of influent and effluent values achieved by both filter chambers. Regardless of the operating phase (see Table 3), COD cleaning performances of both lava sand $(6.3 \pm 3.0 \mathrm{mg} / \mathrm{L})$ and Rhine sand filter $(11.3 \pm 3.9 \mathrm{mg} / \mathrm{L})$ have proven to be very promising (see Table 3). COD load was reduced on average by $98 \%$ in the lava sand chamber and by $96 \%$ in the Rhine sand compartment, thus outperforming wetlands for greywater treatment (see e.g., [17,18]) and municipal water treatment (see e.g., [19,25]). This finding may be due to the treatment of exclusively light greywater, which benefits VFCW operation. Furthermore, COD effluent values remained stable even at very low water temperatures (see Tables 1 and 3). In January 2021, temperatures reached $1.4{ }^{\circ} \mathrm{C}$ in both filter effluents. In all operating phases, COD concentrations were found to lie far below $60 \mathrm{mg} / \mathrm{L}$ COD, above which, according to DIN 19650 [11], a hygienic-microbiological risk cannot be excluded without further measurements. Regarding COD reduction, the lava sand filter performed better than the conventional Rhine sand filter, which may be partially related to the fact that the lava sand filter was operated at slightly lower hydraulic surface loading rates than the Rhine sand filter (see Table 1) due to a height difference between the inlet distribution pipes, which has now been corrected. Most importantly, the better COD efficiencies can presumably be attributed to the higher water-binding capacity of the zeolitecontaining lava sand, when compared to conventional fluviatile sands. Upon contact with water, the higher water absorption capacity leads to swelling of the grain structure and a consequent contraction of pore spaces. This equalizes the distribution of the wastewater within the filter media and reduces hydraulic conductivity, which in turn increases contact time between water and microorganisms [30], thus enhancing treatment efficiency. 


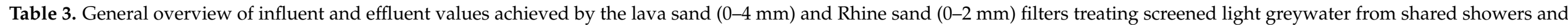
hand wash basins at temporary construction workers' housing in Stuttgart North, in comparison with standards for irrigation water.

\begin{tabular}{|c|c|c|c|c|c|c|c|c|c|c|c|}
\hline \multirow[t]{2}{*}{ Parameter } & \multirow[t]{2}{*}{ Unit } & \multicolumn{3}{|c|}{ Screened Greywater } & \multicolumn{3}{|c|}{$\begin{array}{c}\text { Lava Sand Chamber } \\
\text { HLR }=18-73 \mathrm{~L} /\left(\mathrm{m}^{2} \cdot \mathrm{d}\right) \\
\text { OLR }=8-37 \mathrm{gCOD} /\left(\mathrm{m}^{2} \cdot \mathrm{d}\right)\end{array}$} & \multicolumn{3}{|c|}{$\begin{array}{l}\text { Rhine Sand Chamber } \\
\text { HLR }=22-83 \mathrm{~L} /\left(\mathrm{m}^{2} \cdot \mathrm{d}\right) \\
\text { OLR }=9-46 \mathrm{~g}_{\mathrm{COD}} /\left(\mathrm{m}^{2} \cdot \mathrm{d}\right)\end{array}$} & \multirow[t]{2}{*}{ Irrigation Water Standards } \\
\hline & & $\begin{array}{l}\text { Mean Value } \\
\pm \text { Std. Dev. }\end{array}$ & $\begin{array}{c}\text { Median } \\
\text { (Min-Max) }\end{array}$ & $n$ & $\begin{array}{l}\text { Mean Value } \\
\pm \text { Std. Dev. }\end{array}$ & $\begin{array}{c}\text { Median } \\
\text { (Min-Max) }\end{array}$ & $n$ & $\begin{array}{l}\text { Mean Value } \\
\pm \text { Std. Dev. }\end{array}$ & $\begin{array}{c}\text { Median } \\
\text { (Min-Max) }\end{array}$ & $n$ & \\
\hline COD & $\mathrm{mg} / \mathrm{L}$ & $328 \pm 211$ & $\begin{array}{c}258 \\
(197-1039)\end{array}$ & 20 & $6.3 \pm 3.0$ & $\begin{array}{c}6.0 \\
(2.5-16.8)\end{array}$ & 20 & $11.3 \pm 3.9$ & $\begin{array}{c}11.7 \\
(2.5-17.9)\end{array}$ & 20 & $\begin{array}{l}<60 \mathrm{mg} / \mathrm{L}[11] \text { due to } \\
\text { microbiological-hygienic } \\
\text { concerns }\end{array}$ \\
\hline $\mathrm{N}_{\text {tot }}$ & $\mathrm{mg} / \mathrm{L}$ & $28.3 \pm 7.1$ & $\begin{array}{c}27.9 \\
(19.0-46.8) \\
\end{array}$ & 20 & $25.5 \pm 8.8$ & $\begin{array}{c}25.8 \\
(8.9-37.7)\end{array}$ & 20 & $24.4 \pm 6.7$ & $\begin{array}{c}23.9 \\
(10-37.3)\end{array}$ & 20 & - \\
\hline$P_{\text {tot }}$ & $\mathrm{mg} / \mathrm{L}$ & $1.9 \pm 0.5$ & $\begin{array}{c}1.8 \\
(1.3-3.2)\end{array}$ & 20 & \multicolumn{2}{|c|}{$<0.05$} & 20 & $0.91 \pm 0.36$ & $\begin{array}{c}0.94 \\
(0.16-1.37) \\
\end{array}$ & 20 & - \\
\hline $\mathrm{pH}$ & - & $8.4 \pm 0.3$ & $\begin{array}{c}8.5 \\
(7.6-8.8) \\
\end{array}$ & 18 & $7.5 \pm 0.2$ & $\begin{array}{c}7.5 \\
(7.1-7.7)\end{array}$ & 17 & $7.2 \pm 0.1$ & $\begin{array}{c}7.3 \\
(6.9-7.4)\end{array}$ & 17 & $6-8[12]$ \\
\hline $\mathrm{EC}$ & $\mu \mathrm{S} / \mathrm{cm}$ & $737 \pm 51$ & $\begin{array}{c}722 \\
(678-837)\end{array}$ & 8 & $872 \pm 42$ & $\begin{array}{c}877 \\
(807-943)\end{array}$ & 9 & $860 \pm 36$ & $\begin{array}{c}858 \\
(803-902)\end{array}$ & 9 & $\begin{array}{l}\text { Medium salt tolerance: } \\
300-800 \mu \mathrm{S} / \mathrm{cm}[12] ; \text { salt sensitive } \\
\text { crops: }<1400 \mu \mathrm{S} / \mathrm{cm}[13]\end{array}$ \\
\hline $\mathrm{NO}^{3-}-\mathrm{N}$ & $\mathrm{mg} / \mathrm{L}$ & \multicolumn{2}{|c|}{$<0.23-0.8^{\mathrm{A}}$} & 6 & $23.9 \pm 8.7$ & $\begin{array}{c}23.3 \\
(8.2-38.2)\end{array}$ & 20 & $19.7 \pm 5.5$ & $\begin{array}{c}19.6 \\
(9.6-29.1)\end{array}$ & 20 & - \\
\hline $\mathrm{NO}^{2-}-\mathrm{N}$ & $\mathrm{mg} / \mathrm{L}$ & \multicolumn{2}{|c|}{$<0.015$} & 1 & \multicolumn{2}{|c|}{$<0.015$} & 6 & $0.40 \pm 0.32$ & $\begin{array}{c}0.33 \\
(0.06-0.95) \\
\end{array}$ & 10 & - \\
\hline $\mathrm{NH}^{4+}-\mathrm{N}$ & $\mathrm{mg} / \mathrm{L}$ & $13.9 \pm 5.6$ & $\begin{array}{c}12.8 \\
(2.8-25.9)\end{array}$ & 20 & $0.4 \pm 0.3^{\mathrm{E}}$ & $\begin{array}{c}0.3 \\
(0.05-1.0)\end{array}$ & 17 & $2.3 \pm 1.6^{\mathrm{I}}$ & $\begin{array}{c}1.7 \\
(0.5-4.9)\end{array}$ & 18 & $\begin{array}{c}<1 \mathrm{mg} / \mathrm{L}\left(\mathrm{NH}_{4}^{+}\right)[11] \text { due to } \\
\text { microbiological-hygienic } \\
\text { concerns }\end{array}$ \\
\hline $\mathrm{SO}_{4}^{2-}$ & $\mathrm{mg} / \mathrm{L}$ & \multicolumn{2}{|c|}{$<40-49.7^{\text {B }}$} & 19 & $42 \pm 16^{\mathrm{F}}$ & $\begin{array}{c}50 \\
(20-57)\end{array}$ & 6 & $46 \pm 17^{\mathrm{J}}$ & $\begin{array}{c}53 \\
(20-62)\end{array}$ & 7 & $\begin{array}{c}<250 \mathrm{mg} / \mathrm{L} \text { [31], otherwise } \\
\text { corrosive }\end{array}$ \\
\hline $\mathrm{Cl}^{-}$ & $\mathrm{mg} / \mathrm{L}$ & $58 \pm 8$ & $\begin{array}{c}58 \\
(44-80)\end{array}$ & 18 & $56 \pm 8$ & $\begin{array}{c}57 \\
(44-69)\end{array}$ & 18 & $56 \pm 8$ & $\begin{array}{c}57 \\
(42-66)\end{array}$ & 16 & $\begin{array}{l}\text { Suitable for nearly all plants: } \\
<70 \mathrm{mg} / \mathrm{L} \text { [12]; salt sensitive } \\
\text { crops: }<250 \mathrm{mg} / \mathrm{L}[13]\end{array}$ \\
\hline
\end{tabular}


Table 3. Cont.

\begin{tabular}{|c|c|c|c|c|c|c|c|c|c|c|c|}
\hline \multirow[t]{2}{*}{ Parameter } & \multirow[t]{2}{*}{ Unit } & \multicolumn{3}{|c|}{ Screened Greywater } & \multicolumn{3}{|c|}{$\begin{array}{c}\text { Lava Sand Chamber } \\
\text { HLR }=18-73 \mathrm{~L} /\left(\mathrm{m}^{2} \cdot \mathrm{d}\right) \\
\text { OLR }=8-37 \mathrm{~g}_{\mathrm{COD}} /\left(\mathrm{m}^{2} \cdot \mathrm{d}\right)\end{array}$} & \multicolumn{3}{|c|}{$\begin{array}{c}\text { Rhine Sand Chamber } \\
\text { HLR }=22-83 \mathrm{~L} /\left(\mathrm{m}^{2} \cdot \mathrm{d}\right) \\
\text { OLR }=9-46 \mathrm{~g}_{\mathrm{COD}} /\left(\mathrm{m}^{2} \cdot \mathrm{d}\right)\end{array}$} & \multirow[t]{2}{*}{ Irrigation Water Standards } \\
\hline & & $\begin{array}{l}\text { Mean Value } \\
\pm \text { Std. Dev. }\end{array}$ & $\begin{array}{c}\text { Median } \\
\text { (Min-Max) }\end{array}$ & $n$ & $\begin{array}{l}\text { Mean Value } \\
\pm \text { Std. Dev. }\end{array}$ & $\begin{array}{c}\text { Median } \\
\text { (Min-Max) }\end{array}$ & $n$ & $\begin{array}{l}\text { Mean Value } \\
\pm \text { Std. Dev. }\end{array}$ & $\begin{array}{c}\text { Median } \\
\text { (Min-Max) }\end{array}$ & $n$ & \\
\hline $\mathrm{Na}^{+}$ & $\mathrm{mg} / \mathrm{L}$ & $26.3 \pm 6.2$ & $\begin{array}{c}27.4 \\
(10.8-38.6)\end{array}$ & 19 & $11.8 \pm 6.7^{\mathrm{G}}$ & $\begin{array}{c}11.0 \\
(5.0-35)\end{array}$ & 18 & $28.3 \pm 7.8^{\mathrm{K}}$ & $\begin{array}{c}27.9 \\
(5.0-38.6)\end{array}$ & 19 & $\begin{array}{l}<30 \mathrm{mg} / \mathrm{L} \text { [12]; salt sensitive } \\
\text { crops: < } 150 \mathrm{mg} / \mathrm{L}[13]\end{array}$ \\
\hline $\mathrm{Ca}^{2+}$ & $\mathrm{mg} / \mathrm{L}$ & $63 \pm 12$ & $\begin{array}{c}64 \\
(35-80)\end{array}$ & 19 & $95 \pm 16$ & $\begin{array}{c}100 \\
(58-112)\end{array}$ & 18 & $94 \pm 16$ & $\begin{array}{c}96 \\
(38-116)\end{array}$ & 19 & - \\
\hline $\mathrm{Mg}^{2+}$ & $\mathrm{mg} / \mathrm{L}$ & $9.5 \pm 2.0$ & $\begin{array}{c}10.4 \\
(5.0-12.4)\end{array}$ & 19 & $17.0 \pm 3.0$ & $\begin{array}{c}18.2 \\
(11.3-21.2)\end{array}$ & 18 & $10.4 \pm 2.0$ & $\begin{array}{c}11.0 \\
(4.7-12.7)\end{array}$ & 19 & - \\
\hline $\mathrm{K}^{+}$ & $\mathrm{mg} / \mathrm{L}$ & \multicolumn{2}{|c|}{$<10-72 \mathrm{C}$} & 19 & $23 \pm 16$ & $\begin{array}{c}20.7 \\
(10.4-86)\end{array}$ & 18 & \multicolumn{2}{|c|}{$<10-24^{\mathrm{L}}$} & 19 & - \\
\hline $\begin{array}{l}\text { Non-ionic } \\
\text { surfactants }\end{array}$ & $\mathrm{mg} / \mathrm{L}$ & $6.7 \pm 7.0$ & $\begin{array}{c}4.1 \\
(1.8-16.8)\end{array}$ & 4 & \multicolumn{2}{|c|}{$<0.2$} & 4 & \multicolumn{2}{|c|}{$<0.2-0.3^{\mathrm{M}}$} & 4 & - \\
\hline $\begin{array}{c}\text { cationic } \\
\text { surfactants }\end{array}$ & $\mathrm{mg} / \mathrm{L}$ & $0.9 \pm 0.2$ & $\begin{array}{c}0.9 \\
(0.7-1.2)\end{array}$ & 4 & \multicolumn{2}{|c|}{$<0.2-0.6^{\mathrm{H}}$} & 4 & \multicolumn{2}{|c|}{$0.2-0.7^{\mathrm{N}}$} & 4 & - \\
\hline $\begin{array}{l}\text { anionic } \\
\text { surfactants }\end{array}$ & $\mathrm{mg} / \mathrm{L}$ & $12.9 \pm 2.5$ & $\begin{array}{c}13.7 \\
(9.3-14.9)\end{array}$ & 4 & $0.5 \pm 0.1$ & $\begin{array}{c}0.5 \\
(0.4-0.5)\end{array}$ & 4 & $0.9 \pm 0.2$ & $\begin{array}{c}0.9 \\
(0.6-1.0)\end{array}$ & 4 & - \\
\hline SAR & (mmol/ & ${ }^{1 / 2} 1.6 \pm 0.3$ & $\begin{array}{c}1.6 \\
(0.9-2.3)\end{array}$ & 19 & $0.6 \pm 0.3$ & $\begin{array}{c}0.5 \\
(0.3-1.7)\end{array}$ & 18 & $1.4 \pm 0.3$ & $\begin{array}{c}1.4 \\
(0.4-1.9)\end{array}$ & 18 & $\begin{array}{l}<6(\mathrm{mmol} / \mathrm{L})^{1 / 2}[12], \text { suitable for } \\
\text { irrigation of nearly all soil types }\end{array}$ \\
\hline
\end{tabular}

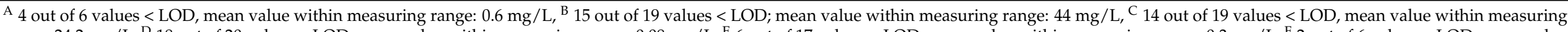

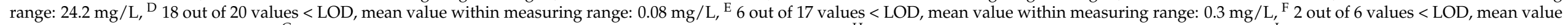

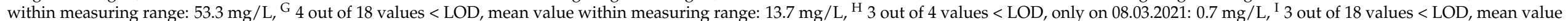

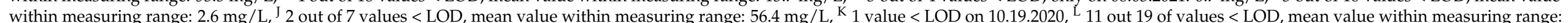
$12.4 \mathrm{mg} / \mathrm{L},{ }^{\mathrm{M}} 2$ out of 4 values < LOD, only on 30.11.2020: $0.29 \mathrm{mg} / \mathrm{L}$ und am 18.01.2021: $0.3 \mathrm{mg} / \mathrm{L}$, ${ }^{\mathrm{N}} 2$ out of 4 values $<\mathrm{LOD}$, only on $18.01 .2021: 0.22 \mathrm{mg} / \mathrm{L}$ and on $08.03 .2021: 0.7 \mathrm{mg} / \mathrm{L}$. 
Assuming a COD/ $\mathrm{BOD}_{5}$ ratio of 2.0 [28] at the inlet as well as typical VFCW overall removal performances of $85 \%$ for $\mathrm{BOD}_{5}$ and $75.2 \%$ for $\mathrm{COD}$ [19], a $\mathrm{COD} / \mathrm{BOD}_{5}$ ratio of 3.4 can be estimated for the effluent water. Hence, estimated $\mathrm{BOD}_{5}$ concentrations lower than $1.8 \pm 0.9 \mathrm{mg} / \mathrm{L}$ and $3.3 \pm 1.1 \mathrm{mg} / \mathrm{L}$ can be expected for the lava sand and the Rhine sand effluent, respectively, as the overall COD removal in this study reached $98 \%$, which is significantly higher than reported literature values. These outstanding concentrations fall below several applicable standards for the unrestricted use of treated wastewater as irrigation water in Germany and elsewhere (Germany: $\mathrm{BOD}_{5}<10 \mathrm{mg} / \mathrm{L}$, see DIN 19650 (1999) [11]; International: $\mathrm{BOD}_{5}<5 \mathrm{mg} / \mathrm{L}$ for very high quality treated wastewater, see ISO 16075-1 (2020) [13]; International: for instance, $\mathrm{BOD}_{5}<10 \mathrm{mg} / \mathrm{L}$, depending on the requirements of the local regulatory agency, see WHO (2006) [14]; European Union: $\mathrm{BOD}_{5}<10 \mathrm{mg} / \mathrm{L}$ for treated water for agricultural irrigation, see EU 2020/741 (2020) [15]). The achieved effluent values show that treating solely light greywater can enhance VFCW performance, as both filter chambers outperform reported efficiencies from the scientific literature (see e.g., $[17,18])$.

\subsection{Nitrification at Low Temperatures}

With regards to nitrification at low temperatures, it can be stated that elevated lava sand VFCW is, in principle, more suitable than the Rhine sand counterpart, yet fluviatile sands are largely commercially available and low-cost. On average, $\mathrm{N}_{\text {tot }}$ concentrations in the lava sand filter effluent amounted to $25.5 \pm 8.8 \mathrm{mg} / \mathrm{L}$, from which $23.9 \pm 8.7 \mathrm{mg} / \mathrm{L}$ were present as $\mathrm{NO}_{3}{ }^{-}-\mathrm{N}$ (see Table 3). Nitrates improve water irrigation quality as they can be considered in the fertilizer balance. However, caution is recommended in case of water infiltration, as high nitrates concentration can compromise quality of drinking water obtained from aquifers. Only minor ammonium nitrogen concentrations $(0.4 \pm 0.3 \mathrm{mg} / \mathrm{L}$, min-max: $0.05-1.0 \mathrm{mg} / \mathrm{L})$ were found in the lava sand chamber effluent during the coldest operating phases, while no nitrite was detectable. Lava sand disposes of a higher cation exchange capacity than conventional fluviatile sands [30], which seems to enhance ammonium retention within the filter media, which in turn, combined with an increased contact time between nitrifying bacteria and greywater due to the ability of the zeolite-containing lava sand to swell, promotes extensive nitrification at all times, even at very low water temperatures near the freezing point. This is an important finding as nitrification is very limited when wastewater temperature is below $10^{\circ} \mathrm{C}$ [32]. In contrast, Rhine sand effluent was found to entail $24.4 \pm 6.7 \mathrm{mg} / \mathrm{L} \mathrm{N}_{\text {tot }}$ (of which only $19.7 \pm 5.5 \mathrm{mg} / \mathrm{L}$ were determined as $\left.\mathrm{NO}_{3}{ }^{-}-\mathrm{N}\right)$ as well as increased concentrations of nitrite $(0.40 \pm 0.32 \mathrm{mg} / \mathrm{L}$ $\mathrm{NO}_{2}{ }^{-}-\mathrm{N}$, reaching up to $0.95 \mathrm{mg} / \mathrm{L}$, see Table 3$)$ and ammonium nitrogen $(2.3 \pm 1.6 \mathrm{mg} / \mathrm{L}$; min-max: 0.5-4.9 mg/L), despite reduced feeding in Phases 5a and 5c (see Table 1). However, a complete collapse of the nitrification was not observed. Incomplete nitrification can be ascribed to the very low water temperatures at the inlet, triggered by the outdoor placement of all storage tanks, in combination with the elevated/unprotected VFCW design (despite insulation), which lacks heat from the soil (when compared with conventional filters that are embedded in the ground). All in all, the authors strongly recommend the use of elevated container-based VFCW filled with zeolite-containing lava sands $(0-4 \mathrm{~mm})$ to treat light greywater from showers and hand wash basins. It is advisable to insulate both the VFCW and the storage tanks to avoid freezing hazard. This opens up diversified planning options for urban areas (e.g., placement of VFCW on paved courtyards, roofs, carports, temporary uses etc.), thus significantly mitigating conflicts over competition for land. For conventional fluviatile sand filters, however, there may be a need to embed them in the ground (conventional design) to avoid low temperatures in the winter that limit nitrification.

\subsection{Phosphorus Retention}

With respect to phosphorus, a significant decrease in elimination performance in the Rhine sand filter was observed over time, which is consistent with findings from the 
scientific literature (see e.g., [19]). Elimination rates for $P_{\text {tot }}$ load varied from $83.4 \%$ in Phase $2,56.8 \%$ in Phase $4 b$ to $18.4 \%$ in Phase $5 c$ (see Table 1). In contrast, the lava sand compartment exhibited $\mathrm{P}_{\text {tot }}$ effluent values $<0.05 \mathrm{mg} / \mathrm{L}$ (LOD) at all times (P elimination rates $>97 \%$ ), which corroborates literature findings of enhanced phosphorus removal in zeolite-containing lava sand $\mathrm{CW}$ that treat municipal wastewater from combined sewer systems in Germany, even after operating times of years $[30,33]$. P removal is improved by the high natural zeolite content of lava sands [33] and the increased contact time between VFCW and porous media in the filter [30].

To the authors' best knowledge, this is the first time that both outstanding COD effluent values $(6.3 \pm 3.0 \mathrm{mg} / \mathrm{L}$; min-max: $2.5-16.8 \mathrm{mg} / \mathrm{L})$ and extremely low-phosphorus effluents $\left(<0.05 \mathrm{mg} / \mathrm{L} \mathrm{P}_{\text {tot }}\right)$ are reported for a single-pass VFCW for greywater treatment that has not been explicitly designed for phosphorus elimination. This makes natural zeolite-containing lava sand $(0-4 \mathrm{~mm})$ a very promising filter material for $\mathrm{CW}$ operation. German technical regulations (see DWA-A 262 (2017) [24]) recommend the use of lava sand filters for municipal wastewater treatment, which will potentially propel its largescale implementation. Further investigation is, however, required to assess hygienicmicrobiological risks and the presence of micropollutants in the effluent.

\subsection{Compliance with Irrigation Water Standards and Further Remarks}

As can be inferred from Table 3, all further investigated parameters in both VFCW effluents complied with irrigation water standards at all times: $\mathrm{pH}$ values within 6-8 [12], sulfate concentrations far below $250 \mathrm{mg} / \mathrm{L}$ [31], chloride contents $<70 \mathrm{mg} / \mathrm{L}$ [12]; natrium concentrations $<30 \mathrm{mg} / \mathrm{L}$ [12] and SAR values $<6(\mathrm{mmol} / \mathrm{L})^{1 / 2}$ [12]. The reduction of $\mathrm{pH} 8.4$ at the inlet to more neutral values in the effluent can possibly be ascribed to a combination of alkalinity consumption through nitrification [34] and exudation of $\mathrm{H}^{+}$/organic acids by roots (see e.g., $[35,36])$. In addition, the EC can become a problem, which was found to be slightly higher than the salt tolerance range for plants with medium salt tolerance [12], yet both effluent values fell far short of the ISO 16075-1 [13] limit recommendation of $1400 \mu \mathrm{S} / \mathrm{cm}$. In any case, the electrical conductivity varies site-specifically. If needed, treated greywater can be blended with rainwater (e.g., from roofs) to reduce EC to a suitable value below $800 \mu \mathrm{S} / \mathrm{cm}$, which is the upper limit stipulated in DIN 19684-10 [12] for plants with moderate salt tolerance. At the Impulse Project, irrigation water for facade greenings is a mixture of $75 / 25$ (vol. \%) treated greywater/rainwater.

Treated greywater entails nutrient contents $(\mathrm{N}, \mathrm{K}, \mathrm{P})$ that can reduce fertilizer demand, thus improving crop fertilization, yet zeolite-containing lava sand significantly retains phosphorus. Furthermore, under the investigated conditions, lava sand seemed to release $\mathrm{Mg}^{2+}, \mathrm{Ca}^{2+}, \mathrm{K}^{+}$into the water, whereas $\mathrm{Na}^{+}$was partially retained (see Table 3); average $\mathrm{Mg}^{2+}$ concentrations went from $9.5 \mathrm{mg} / \mathrm{L}$ at the inlet up to $17.0 \mathrm{mg} / \mathrm{L}$ in the effluent, while $\mathrm{Ca}^{2+}$ contents increased from $65 \mathrm{mg} / \mathrm{L}$ up to $95 \mathrm{mg} / \mathrm{L}$ in the effluent (Table 3). $\mathrm{Ca}^{2+}$ leaching was also observed in the Rhine sand effluent (see Table 3 ). $\mathrm{K}^{+}$contents at the inlet were mostly $<10 \mathrm{mg} / \mathrm{L}\left(\mathrm{LOD}\right.$ ) and reached $23 \mathrm{mg} / \mathrm{L} \mathrm{K}^{+}$on average in the lava sand effluent. Potassium is a macronutrient and can thus improve irrigation water quality as well. In contrast, $\mathrm{Na}^{+}$concentrations were reduced by the lava sand filter from $26 \mathrm{mg} / \mathrm{L}$ at the inlet to $11.8 \mathrm{mg} / \mathrm{L}$ on average, which is consistent with the SAR reduction from $1.6(\mathrm{mmol} / \mathrm{L})^{1 / 2}$ to $0.6(\mathrm{mmol} / \mathrm{L})^{1 / 2}$ by the lava sand filter. This directly benefits soil irrigation. The release of $\mathrm{Mg}^{2+}$ (only valid for lava sand) and $\mathrm{Ca}^{2+}$ into the effluent water may partially elucidate the increase in EC from $737 \pm 51 \mu \mathrm{S} / \mathrm{cm}$ at the inlet up to $872 \pm 42 \mu \mathrm{S} / \mathrm{cm}$ (lava sand) and $860 \pm 36 \mu \mathrm{S} / \mathrm{cm}$ (Rhine sand). Moreover, non-ionic and anionic surfactants were degraded very well by both filter substrates with elimination rates $>93 \%$. Cationic surfactants, which are however only present in traces in light greywater, were eliminated to $70-78 \%$. This highlights the high quality of the treated water. 


\section{Conclusions}

The volume flow of light greywater from showers and hand wash basins at a temporary construction workers' housing site in Germany was estimated to be $48 \mathrm{~L}$ per person and day, thus emphasizing the considerable potential for water reclamation in such facilities. Characterization of greywater has proven to be critical for correct CW sizing, as volume flows and composition can vary significantly from expected values. In addition, screening was shown to be well suitable as a pretreatment step for light greywater (excluding kitchen wastewater and water from washing machines). Hence, there is no further need of settling light greywater (e.g., in a multi-chamber septic tank), which results in a lower total treatment system area, thus promoting VFCW application in built-up inner-city areas. Treated light greywater in both lava sand $(0-4 \mathrm{~mm})$ and Rhine sand $(0-2 \mathrm{~mm})$ filters complied with irrigation standards at all times, yet rainwater blending can help reduce salt contents, if applicable. Furthermore, treated greywater can be an adequate complementary nutrient source for crop irrigation. Besides, the elevated container-based VFCW filled with conventional fluviatile sand exhibited incomplete nitrification at low water temperatures; therefore, there may be a need to embed it into ground (conventional design). In contrast, the elevated lava sand VFCW showed outstanding COD cleaning performances (effluent values: $6.3 \pm 3.0 \mathrm{mg} / \mathrm{L}$ ), extensive nitrification even at extremely low water temperatures and enhanced phosphorus retention (effluent values: $<0.05 \mathrm{mg} / \mathrm{L} \mathrm{P}_{\text {tot }}$ ), which makes the zeolite-containing lava sand $(0-4 \mathrm{~mm})$ a very promising filter material for greywater treatment. All in all, the authors of this study strongly recommend the elevated container-based design for lava sand filters to treat light greywater, as this opens up new opportunities in urban planning, thus mitigating disputes over land in built-up urban areas. Finally, the Stuttgart Impulse Project demonstrates that measures for integrated blue-green planning can be successfully implemented in inner-city districts within a confined space, thus significantly contributing to urban resilience.

Future research includes the VFCW operation at higher organic and hydraulic surface loading rates to determine the required filter area for light greywater treatment, which is likely to lie below $0.5 \mathrm{~m}^{2}$ per person, and the need for amendments in the technical regulations. There is also a need to investigate phosphorus retention in the lava sand compartment in the long-term to determine when and to what extent a phosphorus breakthrough may take place. Additionally, investigations into the VFCW performance on the removal of hygienic-microbiological parameters and selected micropollutants are also scope of ongoing research. Future research will also comprise the sporadic analysis of $\mathrm{BOD}_{5}$ at the wetland inlet and outlet to validate the theoretical assumptions.

Author Contributions: Conceptualization, C.M. and H.S.; methodology C.M., P.M., and G.S.; investigation, C.M., P.M., and G.S.; data processing, P.M. and G.S.; writing-original draft preparation, C.M. and G.S.; writing-review and editing, C.M., G.S., and H.S.; project administration, H.S.; funding acquisition, C.M. and H.S. All authors have read and agreed to the published version of the manuscript.

Funding: This research was funded by the German Federal Ministry for Education and Research (BMBF), grant number 01LR1705B1.

Institutional Review Board Statement: Not applicable.

Informed Consent Statement: Not applicable.

Data Availability Statement: Not applicable.

Acknowledgments: The authors would like to thank all the Impulse Project Stuttgart's Partners for the productive cooperation. Special thanks are due to Ingo Bruch for all the knowledge shared.

Conflicts of Interest: The authors declare no conflict of interest. 


\section{References}

1. IPCC. Global and Sectoral Aspects; Cambridge University Press: New York, NY, USA, 2014; ISBN 9781107058071.

2. EPA. Green Infrastructure for Climate Resiliency. Available online: https://www.epa.gov/green-infrastructure/greeninfrastructure-climate-resiliency (accessed on 2 July 2021).

3. Brears, R.C. Blue and Green Cities: The Role of Blue-Green Infrastructure in Managing Urban Water Resources; Palgrave Macmillan Limited: London, UK, 2018; ISBN 9781137592583.

4. Besir, A.B.; Cuce, E. Green roofs and facades: A comprehensive review. Renew. Sustain. Energy Rev. 2018, 82, 915-939. [CrossRef]

5. Renaturing Cities, 1st ed.; Juvillà Ballester, E. (Ed.) Diputació de Barcelona: Barcelona, Spain, 2019; ISBN 8498038804.

6. DIN EN 16323. Glossary of Wastewater Engineering Terms: Trilingual Version EN 16323:2014; DIN e. V.: Berlin, Germany, 2014; pp. 1-125.

7. Busgang, A.; Friedler, E.; Gilboa, Y.; Gross, A. Quantitative Microbial Risk Analysis for Various Bacterial Exposure Scenarios Involving Greywater Reuse for Irrigation. Water 2018, 10, 413. [CrossRef]

8. Gross, A.; Maimon, A.; Alfiya, Y.; Friedler, E. Greywater Reuse; CRC Press: Boca Raton, FL, USA, 2015; ISBN 978-1-4822-5505-8.

9. Byrne, J.; Dallas, S.; Anda, M.; Ho, G. Quantifying the Benefits of Residential Greywater Reuse. Water 2020, 12, 2310. [CrossRef]

10. GWIG; JBA; Water Corporation WA. The West Australian Greywater Guide: A Source of Practical Information on How to Best Reuse Domestic Greywater in Western Australia; Greywater and Wastewater Industry Group (GWIG): Perth, Australia, 2019.

11. DIN 19650. Bewässerung-Hygienische Belange Von Bewässerungswasser (German Norm: Irrigation-Hygienic Concerns of Irrigation Water); February 1999; Deutsches Institut für Normung e. V. (German Institute for Standardization): Berlin, Germany, 1999.

12. DIN 19684-10. Bodenbeschaffenheit-Chemische Laboruntersuchungen-Teil 10: Untersuchung und Beurteilung Des Wassers Bei Bewässerungsmaßnahmen (German: Soil Properties-Chemical Laboratory Tests_Part 10: Investigation and Evaluation of Water in Irrigation Projects); January 2009; Deutsches Institut für Normung e. V. (German Institute for Standardization): Berlin, Germany, 2009; pp. 1-20.

13. ISO 16075-1. Guidelines for Treated Wastewater Use for Irrigation Projects: Part 1: The Basis of a Reuse Project for Irrigation; ISO 16075-1:2020(E); ISO Copyright Office: Geneva, Switzerland, 2020.

14. WHO. WHO Guidelines for the Safe Use of Wastewater, Excreta and Greywater; World Health Organization: Geneva, Switzerland, 2006; ISBN 92-4-154686-7.

15. Regulation (EU) 2020/741 of the European Parliament and of the Council of 25 May 2020 on Minimum Requirements for Water Reuse. 2020. Available online: https:/ / eur-lex.europa.eu/legal-content/EN/TXT/?uri=CELEX\%3A32020R0741 (accessed on 2 July 2021).

16. Oteng-Peprah, M.; Acheampong, M.A.; de Vries, N.K. Greywater Characteristics, Treatment Systems, Reuse Strategies and User Perception-a Review. Water Air Soil Pollut. 2018, 229, 255. [CrossRef] [PubMed]

17. Arden, S.; Ma, X. Constructed wetlands for greywater recycle and reuse: A review. Sci. Total Environ. 2018, 630, 587-599. [CrossRef] [PubMed]

18. Boano, F.; Caruso, A.; Costamagna, E.; Ridolfi, L.; Fiore, S.; Demichelis, F.; Galvão, A.; Pisoeiro, J.; Rizzo, A.; Masi, F. A review of nature-based solutions for greywater treatment: Applications, hydraulic design, and environmental benefits. Sci. Total Environ. 2020, 711, 134731. [CrossRef] [PubMed]

19. Stefanakis, A.; Akratos, C.S.; Tsihrintzis, V.A. Vertical Flow Constructed Wetlands: Eco-Engineering Systems for Wastewater and Sludge Treatment; Elsevier Science: Burlington, VT, USA, 2014; ISBN 9780124046122.

20. Boyjoo, Y.; Pareek, V.K.; Ang, M. A review of greywater characteristics and treatment processes. Water Sci. Technol. 2013, 67, 1403-1424. [CrossRef] [PubMed]

21. Li, F.; Wichmann, K.; Otterpohl, R. Review of the technological approaches for grey water treatment and reuses. Sci. Total Environ. 2009, 407, 3439-3449. [CrossRef] [PubMed]

22. Stefanakis, A. The Role of Constructed Wetlands as Green Infrastructure for Sustainable Urban Water Management. Sustainability 2019, 11, 6981. [CrossRef]

23. Atanasova, N.; Dalmau, M.; Comas, J.; Poch, M.; Rodriguez-Roda, I.; Buttiglieri, G. Optimized MBR for greywater reuse systems in hotel facilities. J. Environ. Manag. 2017, 193, 503-511. [CrossRef] [PubMed]

24. DWA-A 262. Grundsätze für Bemessung, Bau und Betrieb Von Kläranlagen MIT Bepflanzten und Unbepflanzten Filtern zur Reinigung Häuslichen und Kommunalen Abwassers (German: Principles for Sizing, Construction and Operation of Wastewater Treatment Plants with Planted and Unplanted Filters for the Treatment of Domestic and Municipal Wastewater); November 2017; Deutsche Vereinigung Für Wasserwirtschaft, Abwasser Und Abfall (German Association for Water, Wastewater and Waste): Hennef, Germany, 2017; ISBN 978-3-88721-547-7.

25. Dotro, G.; Langergraber, G.; Molle, P.; Nivala, J.; Puigagut, J.; Stein, O.; von Sperling, M. Biological Wastewater Treatment Series, Volume Seven: Treatment Wetlands. Water Intell Online 2017, 16. [CrossRef]

26. Eisenberg, B.; Morandi, C.; Richter, P.; Well, F.; Winker, M.; Minke, R.; Steinmetz, H.; Ludwig, F. The Impulse Project StuttgartStimulating Resilient Urban Development Through Blue-Green Infrastructure. In Building Resilience to Natural Hazards in the Context of Climate Change; Hutter, G., Neubert, M., Ortlepp, R., Eds.; Springer Fachmedien Wiesbaden: Wiesbaden, Germany, 2021; pp. 157-171. ISBN 978-3-658-33701-8. 
27. Toshovski, S.; Kaiser, M.; Fuchs, S.; Sacher, F.; Thoma, A.; Kümmel, V.; Lambert, B. Prioritäre Stoffe in Kommunalen Kläranlagen-Ein Deutschlandweit Harmonisiertes Vorgehen (German: Priority Substances in Municipal Wastewater Treatment Plants-A Harmonized Approach throughout Germany); 173/2020; Umweltbundesamt (German: Federal Environment Agency): Dessau-Roßlau, Germany, 2020. Available online: https:/ / www.umweltbundesamt.de/publikationen/prioritaere-stoffe-in-kommunalen-klaeranlagen (accessed on 12 March 2020).

28. DWA. New Alternative Sanitation Systems-NASS: Terminology, Material Flows, Treatment of Partial Flows, Utilisation, 1st ed.; Bauhaus-Universität Weimar Publishing House: Kromsdorf, Germany, 2016; ISBN 978-3-95773-213-2.

29. Gesetz Über Die Umweltverträglichkeit Von Wasch-Und Reinigungsmitteln—Wasch-Und Reinigungsmittelgesetz (German: Law on the Environmental Compliance of Detergents and Cleaning Agents-Detergents and Cleaning Agents Act). 2013.

30. Bruch, I.; Fritsche, J.; Bänninger, D.; Alewell, U.; Sendelov, M.; Hürlimann, H.; Hasselbach, R.; Alewell, C. Improving the treatment efficiency of constructed wetlands with zeolite-containing filter sands. Bioresour. Technol. 2011, 102, 937-941. [CrossRef] [PubMed]

31. Verordnung Über Die Qualität Von Wasser Für Den Menschlichen Gebrauch-Trinkwasserverordnung (German: Ordinance on the Quality of Water Intended for Human Consumption-Drinking Water Ordinance): TrinkwV. 2016. Available online: https:/ / www.gesetze-im-internet.de/trinkwv_2001/BJNR095910001.html (accessed on 7 July 2021).

32. WEF. Biological and Chemical Systems for Nutrient Removal; Water Pollution Control Federation; Water Environment Federation: Alexandria, VA, USA, 1998; ISBN 9781572781238.

33. Alewell, C.; Huang, J.-H.; McLaren, T.I.; Huber, L.; Bünemann, E.K. Phosphorus retention in constructed wetlands enhanced by zeolite- and clinopyroxene-dominated lava sand. Hydrol. Process. 2021, 35. [CrossRef]

34. Tchobanoglous, G.; Stensel, H.D.; Tsuchihashi, R.; Burton, F.L.; Abu-Orf, M.; Bowden, G.; Pfrang, W. Wastewater Engineering: Treatment and Resource Recovery, 5th ed.; McGraw-Hill Education: New York, NY, USA, 2014; ISBN 0073401188.

35. Chen, Z.-J.; Tian, Y.-H.; Zhang, Y.; Song, B.-R.; Li, H.-C.; Chen, Z.-H. Effects of root organic exudates on rhizosphere microbes and nutrient removal in the constructed wetlands. Ecol. Eng. 2016, 92, 243-250. [CrossRef]

36. Bezbaruah, A.N.; Zhang, T.C. pH, Redox, and oxygen microprofiles in rhizosphere of bulrush (Scirpus validus) in a constructed wetland treating municipal wastewater. Biotechnol. Bioeng. 2004, 88, 60-70. [CrossRef] [PubMed] 